\title{
TERAPI HIPEROSMOLAR SEBAGAI TATA LAKSANA EDEMA SEREBRI PASCACEDERA KEPALA: LAPORAN KASUS BERBASIS BUKTI
}

\author{
HYPEROSMOLAR THERAPY FOR CEREBRAL EDEMA POST TRAUMATIC BRAIN INJURY: AN \\ EVIDENCE-BASED CASE REPORT \\ Ramdinal Aviesena Zairinal, * Irma Savitri Madjid, * Yetty Ramli, * Diatri Nari Lastri, * Adre Mayza*
}

\begin{abstract}
Mannitol is an agent widely used to treat hyperosmolarity in cases of increased intracranial pressure after acute traumatic brain injury (TBI). Hypertonic saline is an alternative agent in such cases but is still not well-recognized in daily practice. Thus, a literature searching was conducted to see whether mannitol is more effective and safer than hypertonic saline in reducing intracranial pressure in patients with cerebral edema post TBI. The results of literature searching using PubMed, Google Scholar, and Cochrane Database of Systematic Review showed that there is no clear evidence suggesting mannitol is better than hypertonic saline, and vice versa. Therefore, hypertonic saline should be considered as an alternative treatment for hyperosmolarity besides mannitol.
\end{abstract}

Keywords: Cerebral edema, hyperosmolar therapy, hypertonic saline, mannitol, traumatic brain injury

\section{ABSTRAK}

Manitol sebagai agen terapi hiperosmolar untuk menurunkan tekanan intrakranial (TIK) pascacedera kepala telah digunakan secara luas. Sementara pilihan lainnya, yaitu larutan salin hipertonik, masih jarang diaplikasikan pada praktik sehari-hari. Oleh karena itu, dilakukan pencarian literatur untuk menilai efektivitas dan keamanan manitol dibandingkan larutan salin hipertonik dalam menurunkan tekanan intrakranial berdasarkan kasus pasien yang mengalami edema serebri pascacedera kepala. Hasil pencarian di PubMed, Google Scholar, dan Cochrane Database of Systematic Review menunjukkan belum ada bukti ilmiah yang secara tegas menyimpulkan manitol lebih efektif dan aman daripada larutan salin hipertonik maupun sebaliknya. Oleh karena itu, larutan salin hipertonik dapat dijadikan alternatif terapi hiperosmolar selain manitol.

Kata kunci: Cedera kepala, edema serebri, manitol, salin hipertonik, terapi hiperosmolar

*Departemen Neurologi FK Universitas Indonesia/RSUPN Dr. Cipto Mangunkusumo, Jakarta. Korespondensi: ramdinal.md@ui.ac.id. (Makalah ini telah dipresentasikan dalam sesi presentasi oral $16^{\text {th }}$ Asian Oceanian Congress of Neurology 2018)

\section{PENDAHULUAN}

Cedera kepala merupakan salah satu penyebab kegawatdaruratan yang cukup sering ditemui ${ }^{1}$ dan dapat menimbulkan cedera otak sekunder berupa edema serebri dan peningkatan tekanan intrakranial (TIK). ${ }^{2}$ Hal ini dapat ditatalaksana dengan terapi hiperosmolar yang biasa digunakan, yaitu manitol dan larutan salin hipertonik. ${ }^{3}$ Manitol merupakan agen hiperosmolar yang sudah lama dikenal dan telah digunakan secara luas untuk mengurangi edema serebri pascacedera kepala. Larutan salin hipertonik masih jarang diaplikasikan. Namun pemilihan terapi hiperosmolar sebagai tata laksana edema serebri pada kasus cedera kepala yang lebih efektif dan aman di antara kedua agen tesebut masih diperdebatkan, ${ }^{4}$ sehingga dilakukan laporan kasus dengan pendekatan kedokteran berbasis bukti (evidence-based case report/EBCR) ini.

\section{KASUS}

Seorang laki-laki berusia 62 tahun dibawa ke Instalasi Gawat Darurat (IGD) RSCM dengan penurunan kesadaran pascakecelakaan lalu lintas 15 menit sebelum masuk RS. Pemeriksaan awal di IGD menunjukkan pasien tidak merespons terhadap panggilan, jalan napas bebas, laju napas 28 kali/ menit, saturasi oksigen 93\% (ruangan), frekuensi nadi $84 \mathrm{kali} /$ menit dengan irama reguler, dan tekanan darah 123/78mmHg. Pemeriksaan fisik umum didapatkan jejas pada regio temporal kiri dan kanan serta otorrhea telinga kanan. Pemeriksaan neurologis didapatkan GCS E2M5V2=9, pupil bulat isokor diameter $2 \mathrm{~mm} / 2 \mathrm{~mm}$ dengan refleks cahaya lambat, kesan hemiparesis kanan tanpa refleks Babinski, funduskopi kedua mata tidak terdapat papil edema, lain-lain dalam batas normal. 
Hasil laboratorium menunjukkan kadar serum leukosit 12.801/uL, natrium $140 \mathrm{mEq} / \mathrm{L}$, kalium $3,5 \mathrm{mEq} / \mathrm{L}$, klorida $110 \mathrm{mEq} / \mathrm{L}$, glukosa sewaktu $141,3 \mathrm{mg} / \mathrm{dL}$, ureum $25,8 \mathrm{mg} / \mathrm{dL}$, dan kreatinin $1,138 \mathrm{mg} / \mathrm{dL}$. Tidak ada koagulopati pada pasien ini. Hasil CT scan kepala tanpa kontras terdapat edema serebri difus yang disertai kontusio serebri regio temporal kiri, hematoma epidural regio temporal kanan, hematoma subdural frontotemporoparietal kiri, dan perdarahan subaraknoid di temporal kiri, frontal kiri, dan fissura sylvii kiri (Gambar 1).
Secara umum, pasien trauma, terutama cedera kepala, rentan mengalami hipotensi akibat renjatan hemoragik atau pemberian obat-obatan seperti manitol 20\%. Lebih jauh lagi, tekanan darah sistolik di bawah $100 \mathrm{mmHg}$ dapat memengaruhi cerebral perfusion pressure (CPP). ${ }^{5}$ Walaupun pasien ini belum mengalami hipotensi, pemberian manitol 20\% tetap berisiko menuimbulkan hipotensi ke depannya. Hal ini menjadi dasar pemikiran untuk menjadikan salin hipertonik $(\mathrm{NaCl} 3 \%)$ sebagai alternatif terapi hiperosmolar pada kasus cedera kepala.

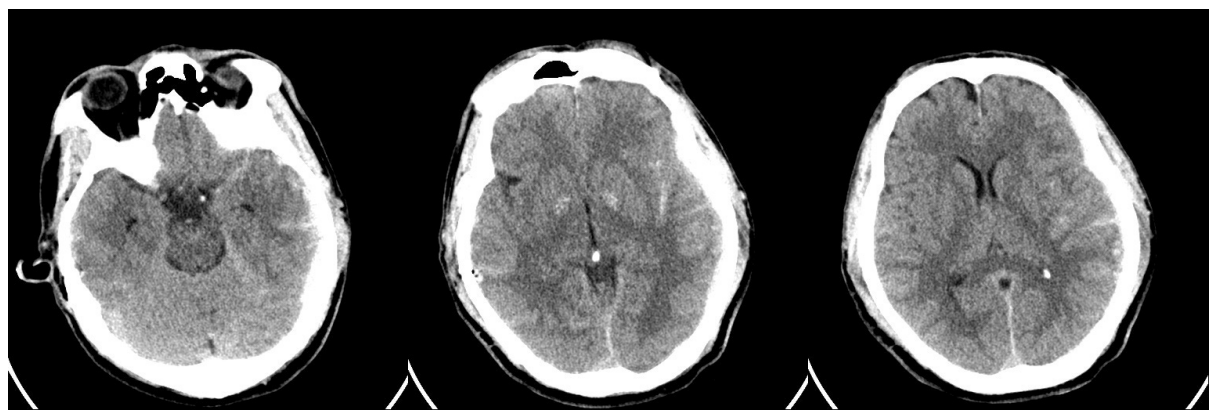

Gambar 1. CT Scan Kepala Pasien (Dokumentasi Pribadi)

Berdasarkan data klinis dan penunjang, pasien mengalami cedera kepala sedang dengan peningkatan tekanan intrakranial akibat edema serebri. Salah satu tata laksana peningkatan tekanan intrakranial pada pasien ini adalah pemberian terapi hiperosmolar untuk mengurangi edema serebri. Pilihan terapi hiperosmolar yang tersedia di Indonesia adalah manitol 20\% dan salin hipertonik ( $\mathrm{NaCl} 3 \%)$. Pada kasus ini, pasien diberikan terapi manitol 20\% 250cc, walaupun sebenarnya terdapat pilihan lain, yaitu $\mathrm{NaCl} 3 \%$, yang bersifat plasma expander dan tidak memiliki efek hipotensi.

Tabel 1. Strategi Pencarian Literatur

\begin{tabular}{|c|c|c|}
\hline Database & Terminologi Pencarian & Hasil Pencarian \\
\hline Pubmed & $\begin{array}{l}\text { (((mannitol[Title/Abstract]) AND (((traumatic brain injury [Title/Abstract]) OR } \\
\text { head trauma [Title/Abstract]) OR head injury)) AND (((intracranial pressure) } \\
\text { OR intracranial hypertension) OR mortality)) AND (((hypertonic saline [Titlel } \\
\text { Abstract]) OR hypertonic sodium [Title/Abstract]) AND “last } 5 \text { years" [PDat] } \\
\text { AND Humans [Mesh] AND English [lang]) AND "last } 5 \text { years" [PDat] AND } \\
\text { Humans [Mesh] AND English [lang] }\end{array}$ & 25 \\
\hline Cochrane Library & $\begin{array}{l}\text { traumatic brain injury AND mannitol AND hypertonic saline AND intracranial } \\
\text { pressure }\end{array}$ & 1 \\
\hline Trip Database & $\begin{array}{l}\text { (title:traumatic brain injury OR head trauma OR head injury)(title:mannitol) } \\
\text { (title:hypertonic saline OR hypertonic sodium)(intracranial pressure OR } \\
\text { intracranial hypertension OR mortality) }\end{array}$ & 6 \\
\hline
\end{tabular}

\section{METODE}

Berdasarkan kasus ini timbul pertanyaan klinis mengenai efektivitas pemberian manitol dalam menurunkan tekanan intrakranial dan mortalitas pasien cedera kepala dibandingkan dengan salin hipertonik. Pertanyaan klinis tersebut diuraikan berdasarkan metode patient, intervention, comparison, outcome (PICO) menjadi: P) Pasien dewasa cedera kepala dengan tanda peningkatan tekanan intrakranial (TIK); I) manitol; C) larutan salin hipertonik; dan O) penurunan tekanan intrakranial dan mortalitas. 
Strategi pencarian literatur dengan memasukkan kata kunci sesuai PICO dilakukan pada tiga database, yaitu Pubmed, Cochrane Library, dan Trip Database (Tabel 1). Kriteria inklusi yang ditetapkan dalam pencarian ini adalah jenis studi uji klinis acak dengan pembanding atau systematic review, publikasi dalam lima tahun terakhir, dan berbahasa Inggris. Pencarian sistematis ini dilakukan pada bulan Agustus 2018.

Literatur artikel yang didapat dari strategi pencarian tersebut selanjutnya ditelaah kritis. Telaah kritis untuk studi systematic review dilakukan dengan menggunakan lembar penilaian FAITH, sedangkan untuk uji klinis acak menggunakan lembar penilaian dari Center for Evidence-Based Medicine (CEBM). ${ }^{6}$ Telaah kritis dilakukan oleh dua orang secara independen. Jika terdapat perbedaan pendapat di antara kedua orang tersebut, maka dilakukan diskusi tatap muka, dan bila perlu, pendapat orang ketiga.

\section{HASIL}

Pencarian literatur yang memenuhi kriteria inklusi menghasilkan 6 artikel (Gambar 1 dan Tabel
2). Terdapat 1 artikel yang mengalami duplikasi judul, sehingga total artikel yang ditelaah kritis sebanyak 5 buah, dengan rincian 4 studi systematic review (Level of Evidence 1a) dan 1 studi uji klinis acak (Level of Evidence 1b).

Tabel 3 menunjukkan telaah kritis hasil pencarian literatur. Pertama, studi oleh Wakai dkk bertujuan mengetahui efektivitas manitol pada cedera kepala, terutama cedera kepala berat. Terdapat empat studi uji klinis acak yang memenuhi kriterianya. Tiap studi memiliki perbedaan dalam hal intervensi kelompok kontrol (Tabel 4), sehingga systematic review ini mempunyai heterogenitas pada aspek klinis. Kelebihan studi Wakai dkk adalah proses pengumpulan studi yang baik. Studi ini sudah mencantumkan pertanyaan dengan formulasi PICO dengan jelas di bagian abstrak dan pendahuluan. Wakai dkk juga mengombinasikan pencarian secara elektronik (pencarian sistematik di database kedokteran) dan manual (hand searching). ${ }^{7}$

Jenis studi yang diinklusikan oleh Wakai dkk yaitu uji klinis acak dengan kontrol, dan tidak

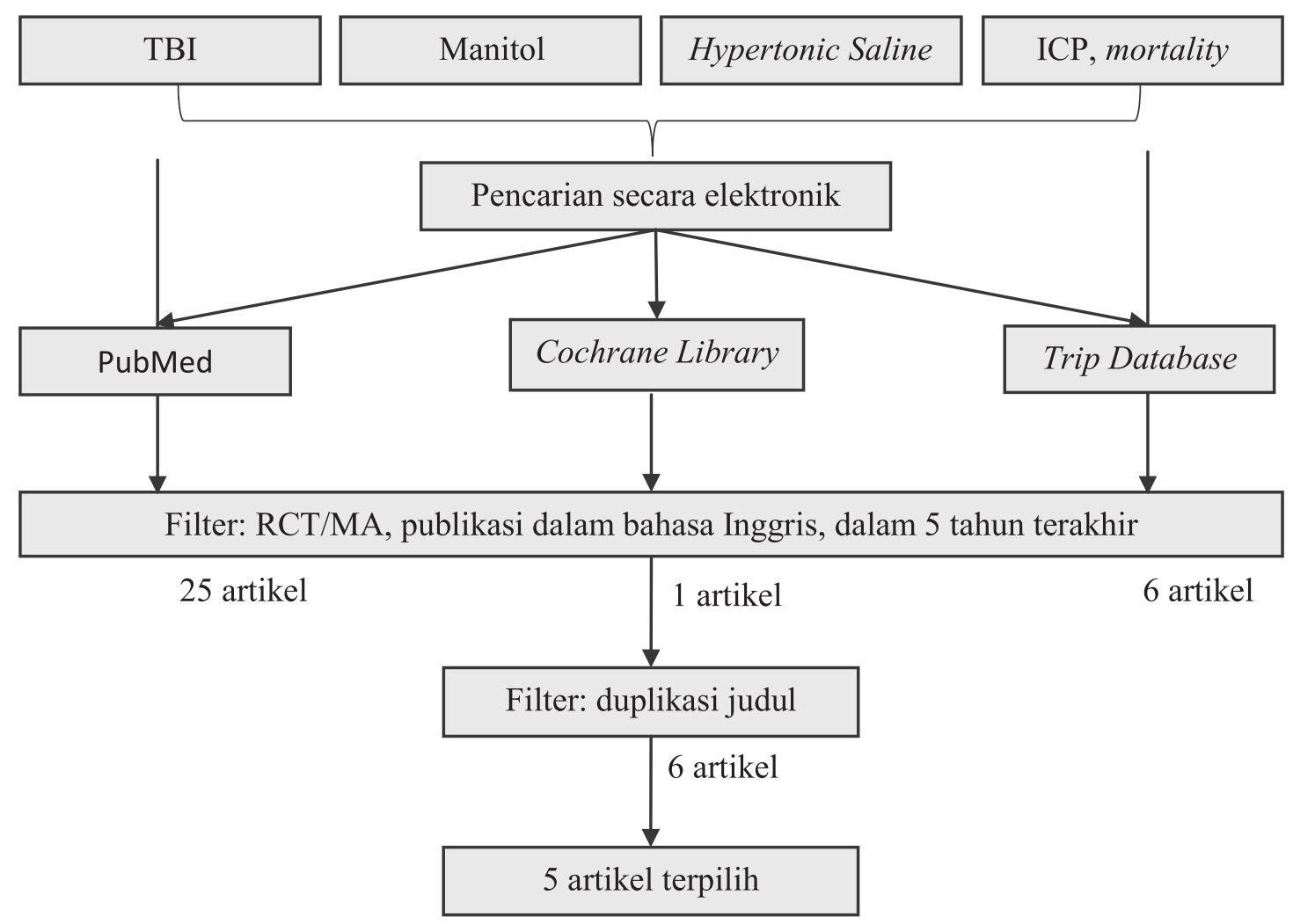

Gambar 2. Hasil Pencarian Literatur

TBI: traumatic brain injury; ICP: intracranial pressure; RCT: randomized controlled trial; MA: meta-analysis. 
Tabel 2. Hasil Studi yang Ditelaah Kritis Berdasarkan Pencarian Literatur

\begin{tabular}{lcccl}
\hline \multicolumn{1}{c}{ Studi } & $\begin{array}{c}\text { Tahun } \\
\text { Publikasi }\end{array}$ & Jenis Studi & Level of Evidence & Tujuan \\
\hline Wakai dkk & 2013 & Systematic review & $1 \mathrm{a}$ & $\begin{array}{l}\text { Menilai efektivitas manitol dibandingkan } \\
\text { dengan regimen lain pada cedera kepala }\end{array}$ \\
\hline Rickard dkk ${ }^{8}$ & 2013 & Systematic review & $1 \mathrm{a}$ & $\begin{array}{l}\text { Membandingkan penggunaan manitol dengan } \\
\text { salin hipertonik dalam mengendalikan TIK } \\
\text { pasien cedera kepala }\end{array}$ \\
\hline Li dkk & 2015 & Systematic review & la & $\begin{array}{l}\text { Membandingkan efektivitas manitol dengan } \\
\text { salin hipertonik untuk menurunkan TIK } \\
\text { pascacedera kepala }\end{array}$ \\
\hline Burgess dkk ${ }^{10}$ & 2016 & Systematic review & $1 \mathrm{a}$ & $\begin{array}{l}\text { Membandingkan manitol dan salin hipertonik } \\
\text { terhadap luaran pasien cedera kepala }\end{array}$ \\
\hline Jagannatha dkk ${ }^{11}$ & 2016 & Uji klinis acak & $1 \mathrm{~b}$ & $\begin{array}{l}\text { Membandingkan efek NaCl3\% dengan manitol } \\
\text { 20\% pada pasien perdarahan intraserebral } \\
\text { traumatik selama } 6 \text { hari }\end{array}$ \\
\hline
\end{tabular}

TIK: tekanan intrakranial.

mengikutsertakan uji dengan cross-over. Namun pada systematic review ini tidak terdapat hasil analisis heterogenitas dan pooled effect yang biasa terlihat pada forest plot, karena keempat studi tersebut tidak dapat dibandingkan satu sama lain. Kekurangan systematic review ini adalah: (1) randomisasi yang tidak jelas dan tidak tersamar (blinding) saat pengambilan data pada sebagian besar studi, sehingga meningkatkan risiko bias; serta (2) besar sampel penelitian pada masing-masing studi tergolong sedikit, sehingga menimbulkan hasil yang kurang presisi. Kesimpulan systematic review ini menyatakan bahwa efektivitas manitol pada cedera kepala, terutama dalam hal mencegah kematian, masih belum bermakna (Tabel 4). ${ }^{7}$

Systematic review oleh Rickard dkk dari enam studi yang terkumpul bertujuan secara spesifik membandingkan manitol dan salin hipertonik dalam mengontrol TIK pasien cedera kepala. Systematic review ini sudah mencantumkan dengan jelas masalah dan formulasi PICO di bagian abstrak dan pendahuluan. Setiap studi yang didapat juga telah ditelaah secara kritis dan risiko bias telah dinilai dengan menggunakan Cochrane collaboration's tool. Penilaian heterogenitas statistik sudah dinilai dengan nilai $\mathrm{I}^{2}$ dan nilai P pada forest plot sebesar $38,1 \%$ dan $0,152 .^{8}$

Namun systematic review tersebut memiliki beberapa kekurangan, yaitu: (1) cara randomisasi dan blinding masih belum jelas pada 4 dari 6 studi; (2) terdapat heterogenitas klinik yang cukup nyata, meliputi variasi pada dosis dan konsentrasi salin hipertonik, ambang batas tekanan intrakranial yang dianggap abnormal, dan waktu penilaian luaran; (3) mengikutsertakan studi kohort retrospektif, yang bukan merupakan pilihan utama dalam jenis studi terkait terapi, dan memasukkan pasien selain cedera kepala. Hasil pooled effect pada systematic review ini menunjukkan tidak ada perbedaan rerata penurunan TIK yang signifikan antara kelompok manitol dengan salin hipertonik, yaitu 1,39 (IK 95\%-0,74; SD 3,53). Walaupun dua studi retrospektif sudah dieksklusi dalam perhitungan di forest plot, hasil ini tetap tidak menunjukkan risiko relatif (RR) kesuksesan terapi yang bermakna secara statistik, yaitu 1,05 (IK 95\% 0,94; SD 1,19). ${ }^{8}$

Adapun systematic review oleh $\mathrm{Li} \mathrm{dkk}$ didapat dari 7 studi yang bertujuan membandingkan efektivitas manitol dengan salin hipertonik dalam menurunkan TIK pasien cedera kepala. Luaran yang dinilai dalam efektivitas ini adalah nilai TIK pada saat awal terapi, menit ke-30, 60, dan 120. Selain itu, osmolaritas juga dinilai. Studi ini tidak mencantumkan penilaian luaran jangka panjang, seperti mortalitas atau Glasgow Outcome Scale (GOS). Formulasi PICO dapat dengan mudah ditemukan di bagian abstrak dan pendahuluan. Sayangnya systematic review ini mencakup studi retrospektif. Hal ini mengakibatkan 
Tabel 3. Ringkasan Hasil Telaah Kritis Artikel Systematic Review

\begin{tabular}{|c|c|c|c|c|c|c|}
\hline Studi & Q & $\mathbf{F}$ & A & I & $\mathbf{T}$ & $\mathbf{H}$ \\
\hline Wakai dkk & + & + & + & + & + & $+/-$ \\
\hline Rickard dkk & + & + & + & $+/-$ & + & + \\
\hline Li dkk & + & - & + & - & + & + \\
\hline Burgess dkk & + & + & + & + & + & + \\
\hline
\end{tabular}

$(+)=$ ya. $(-)=$ tidak. $(+/-)=$ tidak jelas; $\mathrm{Q}=$ Does the systematic review address a focused question $(\mathrm{PICO}) ? ; \mathrm{F}=$ Did the search find all the relevant evidence? $\mathrm{A}=$ Have the studies; been critically appraised? $\mathrm{I}=$ Did they only include high quality studies?; $\mathrm{T}=$ Have the results been totaled up with appropriate tables and plots?; $\mathrm{H}=$ Have the heterogeneity between studies assessed and explained?

Tabel 4. Intervensi pada Setiap Studi di Systematic Review Wakai dkk ${ }^{7}$

\begin{tabular}{|c|c|c|c|}
\hline Studi & Intervensi Kelompok Uji & $\begin{array}{l}\text { Intervensi Kelompok } \\
\text { Kontrol }\end{array}$ & $\begin{array}{l}\text { Risiko Relatif } \\
\text { Mortalitas }\end{array}$ \\
\hline Sayre (1996) & Manitol 20\% & $\mathrm{NaCl} 0,9 \%$ & $\begin{array}{l}1,75(\text { IK } 95 \% 0,48 \\
\text { SD } 6,38)\end{array}$ \\
\hline Schwartz (1984) & Manitol 20\% & Pentobarbital & $\begin{array}{l}0,85(\mathrm{IK} 95 \% 0,52 \\
\text { SD } 1,38)\end{array}$ \\
\hline Smith (1986) & $\begin{array}{l}\text { Manitol } 20 \% \text {, berdasarkan penilaian klinis, } \\
\text { analisis gas darah, dan kondisi ventilasi }\end{array}$ & $\begin{array}{l}\text { Manitol 20\%, berdasarkan } \\
\text { nilai TIK }\end{array}$ & $\begin{array}{l}0,83(\mathrm{IK} 95 \% 0,47 \\
\text { SD } 1,46)\end{array}$ \\
\hline Vialet (2003) & Manitol 20\% & $\mathrm{NaCl} 7,5 \%$ & $\begin{array}{l}1,25(\mathrm{IK} 95 \% 0,47 \\
\text { SD 3,33) }\end{array}$ \\
\hline
\end{tabular}

IK: interval kepercayaan; SD: standar deviasi.

hasil pencariannya tidak sepenuhnya relevan dan berkualitas baik. Ketujuh studi yang terkumpul telah ditelah kritis dan dinilai risiko biasnya dengan menggunakan perangkat dari Cochrane Handbook for Systematic Reviews of Interventions oleh dua mitra bestari (reviewer). ${ }^{9}$

Hasil systematic review oleh Li dkk tersebut tidak jauh berbeda dengan 2 systematic review sebelumnya, yaitu sebagian besar studi yang diikutsertakan berisiko tinggi terkait blinding pada saat perekrutan subjek, pemantauan, dan penilaian luaran. Tidak ada bias publikasi pada systematic review ini, yang ditandai dengan gambaran distribusi simetris pada funnel plot dan Egger's test ( $\mathrm{p}=0,118)$. Pada bagian hasil, terdapat forest plot untuk masingmasing luaran, yaitu penurunan TIK dan osmolaritas. Tidak semua studi memiliki data luaran berupa nilai
TIK pada saat awal, menit ke-30, 60, dan 90. Selain itu, konsentrasi manitol (20\% dan $25 \%$ ) serta larutan salin hipertonik $(7,5 \%$ dan $15 \%)$ yang digunakan pada setiap studi tidak seragam. Kedua hal tersebut menyebabkan adanya heterogenitas dalam aspek klinis. ${ }^{9}$

Penilaian heterogenitas secara statistik menunjukkan kedua luaran tersebut tergolong homogen, dengan nilai $\mathrm{I}^{2} 29,57 \%$ dan nilai $\mathrm{p}=0,213$ untuk penurunan TIK dan $\mathrm{I}^{2} 0 \%$ dan nilai $\mathrm{p}=0,599$ untuk osmolaritas. Hasil berikutnya dari pooled effect menunjukkan salin hipertonik lebih efektif menurunkan TIK dibandingkan manitol pada menit ke-60, 90, dan secara keseluruhan. Di lain pihak, dalam hal osmolaritas tidak terdapat perbedaan bermakna antara manitol dan salin hipertonik (Tabel 5). Secara keseluruhan, systematic review

Tabel 5. Hasil Pooled Effect Systematic Review Li dkk9

\begin{tabular}{lccl}
\hline \multicolumn{1}{c}{ Luaran } & Perbedaan Rerata & $\mathbf{p}$ & Interpretasi \\
\hline Penurunan TIK pada menit ke-30 & $-0,87$ & 0,316 & Manitol= salin hipertonik \\
Penurunan TIK pada menit ke-60 & $-2,58$ & 0,005 & Salin hipertonik $>$ manitol \\
Penurunan TIK pada menit ke-90 & $-4,04$ & 0,004 & Salin hipertonik $>$ manitol \\
Penurunan TIK secara keseluruhan & $-1,69$ & 0,008 & Salin hipertonik $>$ manitol \\
Osmolaritas & 1,84 & 0,301 & Manitol= salin hipertonik \\
\hline
\end{tabular}

TIK: tekanan intrakranial. 
ini menyatakan bahwa salin hipertonik lebih baik daripada manitol dalam hal menurunkan TIK pada pasien cedera kepala. ${ }^{9}$

Selanjutnya, systematic review oleh Burgess dkk berasal dari 5 buah studi yang bertujuan membandingkan manitol dengan larutan salin hipertonik pada pasien cedera kepala dalam hal luaran mortalitas, disabilitas, perubahan TIK, dan kegagalan tata laksana TIK. Formulasi PICO ditemukan di bagian abstrak dan pendahuluan. Jenis studi yang dinklusi pada systematic review ini hanya uji klinis acak. Dengan demikian, ketujuh studi yang didapat relevan dengan masalah yang ingin dijawab dan berkualitas baik. Semua studi telah ditelaah kritis dengan menilai risiko bias. ${ }^{10}$

Gambaran distribusi simetris pada funnel plot menunjukkan tidak ada bias publikasi dalam systematic review tersebut. Kelima studi yang terkumpul tergolong homogen, dengan uji heterogenitas nilai $\mathrm{p}=0,56$ dan $\mathrm{I}^{2} 0 \%$. Hasil forest plot menunjukkan pooled effect untuk kejadian kegagalan tata laksana TIK lebih sering ditemukan pada kelompok manitol daripada salin hipertonik, dengan nilai $\mathrm{p}=0,01$ dan risiko relatif 0,39 (IK $95 \% 0,18-0,81)$. Berbeda dengan ketiga systematic review sebelumnya, dari kelima studi yang ada di systematic review ini, dapat dibuat tabel $2 \times 2$ untuk menilai number needed to treat (NNT), yaitu sekitar 8 (Tabel 6). Dengan demikian, systematic review ini menyatakan bahwa salin hipertonik lebih baik daripada manitol dalam hal keberhasilan tata laksana TIK. ${ }^{10}$

Tabel 6. Luaran TIK pada Kelompok Manitol dan Salin Hipertonik (Pooled Effect) ${ }^{10}$

\begin{tabular}{lccc}
\hline \multirow{2}{*}{$\begin{array}{c}\text { Jenis } \\
\text { Intervensi }\end{array}$} & \multicolumn{2}{c}{ Kegagalan Tata Laksana } & \multirow{2}{*}{ Total } \\
\cline { 2 - 3 } & GIK & Gagal & Berhasil \\
\hline Salin hipertonik & 9 & 117 & 126 \\
Manitol & 23 & 95 & 118 \\
Total & 32 & 212 & 244 \\
\hline
\end{tabular}

TIK: tekanan intrakranial.

Uji klinis oleh Jagannatha dkk membandingkan pemberian manitol $20 \%$ dengan $\mathrm{NaCl} 3 \%$ pada 38 pasien dewasa (20 pasien dengan manitol dan 18 pasien dengan $\mathrm{NaCl} 3 \%$ ) cedera kepala yang mengalami peningkatan TIK selama 6 hari pascaawitan. Luaran yang dinilai meliputi efek jangka pendek (reduksi TIK) dan jangka panjang (lama rawat, mortalitas, dan GOS). Kelebihan studi ini adalah melakukan randomisasi berbasis komputer tetapi tidak tersamar ganda. Hal ini tidak menjadi suatu kekurangan, mengingat parameter luaran diukur melalui alat ukur yang objektif, misalnya monitor TIK. Kekurangan dari metode studi ini adalah cara analisis hasilnya bukan menggunakan intention-to-treat analysis, melainkan per protocol analysis. Hasil studi menunjukkan tidak terdapat perbedaan rerata penurunan TIK yang signifikan dan angka mortalitas di antara kelompok manitol dan $\mathrm{NaCl} 3 \%{ }^{11}$

\section{PEMBAHASAN}

Berdasarkan hasil telaah kritis kelima studi secara umum dapat disimpulkan bahwa belum ada studi yang secara tegas menyatakan superioritas manitol maupun salin hipertonik. Seluruh studi yang ditelaah pada tulisan ini memiliki metode penelitian yang baik.

Terkait validity, keempat systematic review telah mengikuti kaidah penyusunan systematic review seperti memformulasikan pertanyaan klinis, menjelaskan strategi pencarian dan menilai risiko bias. Walaupun seluruh studi yang ada di systematic review kali ini memiliki kelemahan dalam hal blinding, tetapi tidak terlalu berdampak signifikan. Hal ini karena luaran yang diukur bersifat absolut, misalnya mortalitas, nilai TIK dari monitor, dan hasil lab osmolaritas. Selain itu, sebuah telaah kritis mengenai uji klinis acak yang dimasukkan dalam hasil pencarian literatur juga telah mengikuti kaidah penyusunan artikel terapi seperti menjelaskan proses randomisasi, mendeskripsikan kemiripan kelompok kontrol dan subjek serta metode analisis data, sehingga juga dianggap valid.

Terkait importance, seluruh studi yang ditelaah, baik systematic review maupun uji klinis, tidak konklusif dan tidak menyatakan perbedaan yang bermakna antara terapi kontrol. Masing-masing studi mengikutsertakan artikel yang sangat heterogen atau bahkan artikel yang sangat sedikit sehingga 
heterogenitas tidak dapat dinilai, seperti artikel oleh Wakai dkk. Oleh sebab itu, secara garis besar aspek importance kelima artikel yang ditelaah kurang baik.

Terkait applicability, sebagian besar studi yang ada di keempat systematic review menggunakan $\mathrm{NaCl}$ dengan konsentrasi lebih dari 3\%, sehingga sulit untuk diaplikasikan karena faktor ketersediaan di Indonesia. Hanya satu uji klinis acak yang membandingkan manitol 20\% dengan $\mathrm{NaCl} 3 \%$, yang hasil dapat diaplikasikan pada praktik sehari-hari.

Oleh karena itu, tulisan ini tidak dapat merekomendasikan satu agen hiperosmolar lebih baik dibandingkan yang lain. Baik manitol maupun salin hipertonik sama-sama menunjukkan luaran yang tidak berbeda secara signifikan dalam hal penurunan TIK dan mortalitas. Keduanya telah digunakan secara luas di seluruh dunia sebagai agen terapi hiperosmolar. ${ }^{4}$

Salin hipertonik, termasuk $\mathrm{NaCl} 3 \%$ yang tersedia di Indonesia, dapat digunakan sebagai alternatif terapi hiperosmolar. ${ }^{4}$ Namun demikian, pemberian manitol yang telah dilakukan pada skenario klinis ini tetap dapat dijalankan dengan beberapa pertimbangan.

Pertama, terdapat beberapa keterbatasan pada bukti ilmiah yang dikaji. Hingga saat ini, belum ada uji klinis yang membandingkan manitol dengan salin hipertonik yang memiliki jumlah sampel besar dan menunjukkan hasil yang konklusif. Dosis manitol dan salin hipertonik yang dipakai dalam studi yang diikutsertakan di telaah kritis ini masih heterogen dan sebagian besar membatasi penelitian pada pasien cedera kepala berat saja. Hasil penelitian masih dapat digunakan pada pasien cedera kepala sedang karena masih dalam spektrum klinis yang sama. Perlu diperhatikan bahwa kedua agen hiperosmolar terbukti menurunkan TIK, tetapi belum memberi perbedaan manfaat yang signifikan pada luaran neurologis jangka panjang.

Kedua, terdapat perbedaan dalam pemilihan agen hiperosmolar di kalangan klinisi. Sebuah penelitian oleh Berger-Pelleiter ${ }^{12}$ di Kanada mensurvei preferensi dokter mengenai penggunaaan manitol vs salin hipertonik. Manitol dianggap lebih memiliki efek klinis yang lebih kuat dan lebih sering digunakan. Survei lain yang dilakukan di kalangan neurointensivis juga menunjukkan hasil proporsi kedua kelompok manitol dan salin hipertonik tidak jauh berbeda, yaitu berurutan $45,1 \%$ dan $54,9 \%$. Pada survei ini, alasan utama responden lebih memilih manitol adalah karena faktor pengalaman dan tidak memerlukan akses vena sentral. Sebaliknya, alasan utama penggunaan salin hipertonik antara lain, risiko rebound edema lebih kecil, durasi manfaat obat yang lebih panjang, dan kurang memiliki efek samping sistemik. ${ }^{4}$

Adapun alasan mengapa manitol diberikan pada kasus ini adalah preferensi tenaga medis yang lebih terbiasa menggunakan manitol dibandingkan salin hipertonik dalam praktik sehari-hari. Hal ini tercermin dari konsensus yang ada di Indonesia. Secara keilmuan, konsensus trauma kepala di Indonesia saat ini masih mengacu ke manitol. ${ }^{13}$ Dengan mempertimbangkan faktor kebiasaan dan referensi yang ada saat ini di Indonesia, maka manitol lebih sering dipakai daripada salin hipertonik. Keunggulan manitol dibandingkan salin hipertonik dalam hal kepraktisan adalah pemberiannya yang tidak memerlukan akses vena sentral. Meskipun demikian, salin hipertonik dapat dipertimbangkan karena tidak menyebabkan hipotensi. ${ }^{4}$

\section{KESIMPULAN}

Pemberian manitol tidak lebih efektif daripada salin hipertonik dalam hal penurunan TIK dan mortalitas. Hingga saat ini belum ada bukti yang menunjukkan perbedaan signifikan antara kedua regimen tersebut dalam hal penurunan TIK, mortalitas, dan kualitas hidup jangka panjang pasien cedera kepala. Pada situasi bahwa sesungguhnya tidak ada perbedaan bermakna antara kedua jenis terapi terhadap suatu luaran, maka dasar pertimbangan pemilihan jenis terapi tersebut adalah faktor aplikabilitas, atau dengan kata lain adalah sejauh mana hal tersebut bisa diterapkan pada pasien sehari-hari. Oleh karena itu, berdasarkan skenario klinis, manitol masih bisa digunakan sebagai terapi hiperosmolar pada kasus cedera kepala dengan tanda herniasi. 


\section{DAFTAR PUSTAKA}

1. Center for Disease Control and Prevention, National Center for Injury Prevention and Control, Division of Unintentional Injury Prevention. Traumatic brain injury in the united states: Epidemiology and rehabilitation. United States: US Department of Health and Human Services; 2015.

2. McGinn MJ, Povlishock JT. Pathophysiology of traumatic brain injury. Neurosurg Clin N Am. 2016;27(4):397-407.

3. Boone MD, Oren-Grinberg A, Robinson TM, Chen CC, Kasper EM. Mannitol or hypertonic saline in the setting of traumatic brain injury: What have we learned?. Surg Neurol Int. 2015;6:177.

4. Hays AN, Lazaridis C, Neyens R, Nicholas J, Gay S, Chalela JA. Osmotherapy: Use among neurointensivists. Neurocrit Care. 2011;14(2):222-8.

5. Garvin R, Mangat HS. Emergency neurological life support: Severe traumatic brain injury. Neurocrit Care. 2017;27(Supl 1):159-69.

6. Centre for Evidence-Based Medicine. Systematic review critical appraisal sheet. 2018 [diunduh 1 Oktober 2018]. Tersedia dari: CEBM.

7. Wakai A, McCabe A, Roberts I, Schierhout G. Mannitol for acute traumatic brain injury. Cochrane Database Syst Rev. 2013;5(8):CD001049.

8. Rickard AC, Smith JE, Newell P, Bailey A, Kehoe A,
Mann C. Salt or sugar for your injured brain? A metaanalysis of randomised controlled trials of mannitol versus hypertonic sodium solutions to manage raised intracranial pressure in traumatic brain injury. Emerg Med J. 2014;31(8):679-83.

9. Li M, Chen T, Chen SD, Cai J, Hu YH. Comparison of equimolar doses of mannitol and hypertonic saline for the treatment of elevated intracranial pressure after traumatic brain injury: A systematic review and metaanalysis. Medicine (Baltimore). 2015;94(17):e736.

10. Burgess S, Abu-Laban RB, Slavik RS, Vu EN, Zed PJ. A Systematic review of randomized controlled trials comparing hypertonic sodium solutions and mannitol for traumatic brain injury: Implications for emergency department management. Ann Pharmacother. 2016;50(4):291-300.

11. Jagannatha AT, Sriganesh K, Devi BI, Rao GS. An equiosmolar study on early intracranial physiology and long term outcome in severe traumatic brain injury comparing mannitol and hypertonic saline. J Clin Neurosci. 2016;27:68-73.

12. Berger Pelletier E, Emond M, Lauzier F, Savard M, Turgeon AF. Hyperosmolar therapy in severe traumatic brain injury: A survey of emergency physicians from a large Canadian province. PLoS One. 2014;9(4):e95778.

13. Perdossi. Konsensus nasional penanganan trauma kapitis dan trauma spinal. Jakarta: Perdossi; 2006. 